${ }^{2}$ BELLROSE, F. C. Jr. 1976. Ducks, geese and swans of North America. Stackpole Books, Harrisburg, Pa. 543 pp.

${ }^{3}$ COOKE, F., R. K. ROSS, R. K. SCHMIDT and A. J. PAKULAK. 1975. Birds of the tundra biome at Cape Churchill and La Perouse Bay. Can. Field-Nat. 89:413422.

${ }^{4}$ GODFREY, W. E. 1966. The birds of Canada. Nat. Mus. Canada, Bull. 203. $428 \mathrm{pp}$.

${ }^{5}$ HARPER, F. 1953. Birds of the Nueltin Lake expedition, Keewatin, 1947. Am. Midl. Nat. 49:1-116.
${ }^{6} \mathrm{JEHL}$, J. R., Jr., and B. A. SMITH. 1970. Birds of the Churchill region, Manitoba. Manitoba Mus. Man and Nature, Spec. Publ. 1. $87 \mathrm{pp}$.

${ }^{7}$ MOWAT, F. M. and A. H. LAWRIE. 1955. Bird observations from southern Keewatin and the interior of northern Manitoba. Can. Field-Nat. 69:93-116.

${ }^{8} \mathrm{NERO}, \mathrm{R}$. W. 1967 . The birds of northeastern Saskatchewan. Saskatchewan Nat. Hist. Soc., Spec. Publ. 6. 96 pp.

${ }^{9}$ TAVERNER, P. A. and G. M. SUTTON. 1934. The birds of Churchill, Manitoba. Annals Carnegie Mus. 23:1-83.

\title{
PRINCE ALBERT BLUEBIRD TRAIL REPORT - 1981
}

KEVIN ASCHIM, 1175-22nd Street East, Prince Albert, Saskatchewan, S6V 1P2 and KIM HRUSKA, 841-22nd Street East, Prince Albert, Saskatchewan. S6V 1 N9.

This report contains the results of the 1981 season for the Prince Albert Bluebird Trail. In all, 106 nest boxes were checked between 22 July and 27 July.

This year, we found one Tree Swallow nest that contained nine young, the most we have ever had in a single box. Prior to this, we had only occasionally found boxes that contained eight young.

\section{Occupancy of 106 boxes}

$\begin{array}{lr}\text { Tree Swallow } & 76 \\ \text { House Sparrow } & 23 \\ \text { Mountain Bluebird } & 1 \\ \text { Empty } & 6\end{array}$

Tree Swallow Mortality - 2.6\%

Tree Swallow Average Clutch Size - 5.7

Tree Swallow Average Fledged 5.4
House Sparrows have been only a minor annoyance in the past. However, this year they burgeoned to 23 of 106 boxes from only 5 of 108 boxes last year.

Among the six empty boxes, three that were adjacent to poplar bluffs contained a loose aggregation of twigs, likely House Wrens' attempts at preventing an intrusion into their territory.

\section{Success}

Young fledged

Young died

410
77
7 (all destroyed)

11

1 
In the past, we have had good success with Tree Swallows and few problems with House Sparrows but great difficulty in establishing the Mountain Bluebird in our nest boxes. Within the past 5 years we have had only two Mountain Bluebird nests, although there have been many sightings in the area. Because of this, we are taking down many sections of the trail located along unsuitable stretches and moving them exclusively to pastureland habitat more appropriate to bluebirds. Perhaps this will lead to more promising results in future years.

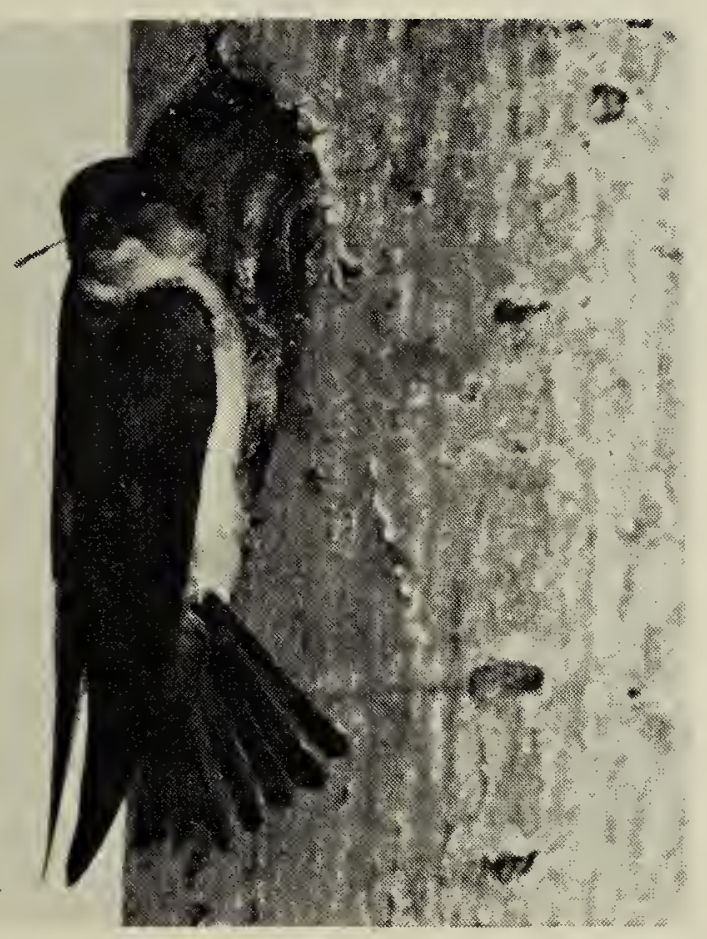

Tree Swallow.

Kathy Morck

\section{NEW RECORD OF A SUMMER TANAGER IN MANITOBA}

RICHARD C. ROUNDS, Department of Geography, Brandon University, Brandon, Manitoba. R7A 6A9

On 13 June 1981, a Summer Tanager was found dead after collision with a window on a farm $2 \mathrm{~km}$ northwest of Brandon, Manitoba. The specimen is a male in pre-adult plumage that is highly varied in color and pattern. The head is irregularly patterned in olive, red and yellow and the breast in red and yellow. The back, wings and tail are olive-brown to orange-brown. The extent of red in the plumage and overall coloration corresponds to that described by Pearson and Godfrey. ${ }^{2}$ No black feathers are evident and the upper mandible lacks the pronounced tooth characteristic of other tanagers. Dissection revealed enlarged testes and the bird was presumed to be in breeding condition.

Only three previous specimens of Summer Tanager have been collected in Manitoba. A pre-adult male similar to that reported above was found near The Pas in 1966. ${ }^{1}$ This species is listed as accidental in southeastern Manitoba where the two records reported are based on specimens in the Manitoba Museum of Man and Nature from Woodlands 24 May 1966 (1st year male) and from Selkirk 11-18 November 1978 (H.W.R. Copland, pers. comm.). ${ }^{4}$ There is also a sight record near Portage La Prairie for 28 May 1953. ${ }^{3}$ The Brandon specimen is preserved as a whole mount in the B.J. Hales Museum, Brandon University, Brandon, Manitoba.

I thank Tony Miller and Barbara Robinson for assistance in identification. David Brownridge notified the author of the location of the bird.

${ }^{1}$ GODFREY, W.E. 1966a. A Summer Tanager in Manitoba. Canadian FieldNat. 80:254.

${ }^{2}$ GODFREY, W.E. 1966b. The birds of Canada. Nat. Mus. Canada Bull. 203. 428 $\mathrm{pp}$.

${ }^{3}$ LAWRENCE, A.G. Chickadee notes No. 1678. Winnipeg Free Press, 17 July 1953.

${ }^{4} M A N I T O B A$ NATURALISTS SOCIETY. 1980. Birder's guide to southeastern Manitoba. Eco Series No. 1, Winnipeg. 58 pp.

${ }^{5}$ PEARSON, T.G., Ed. 1917. Birds of America. Doubleday \& Company Inc., New York. 